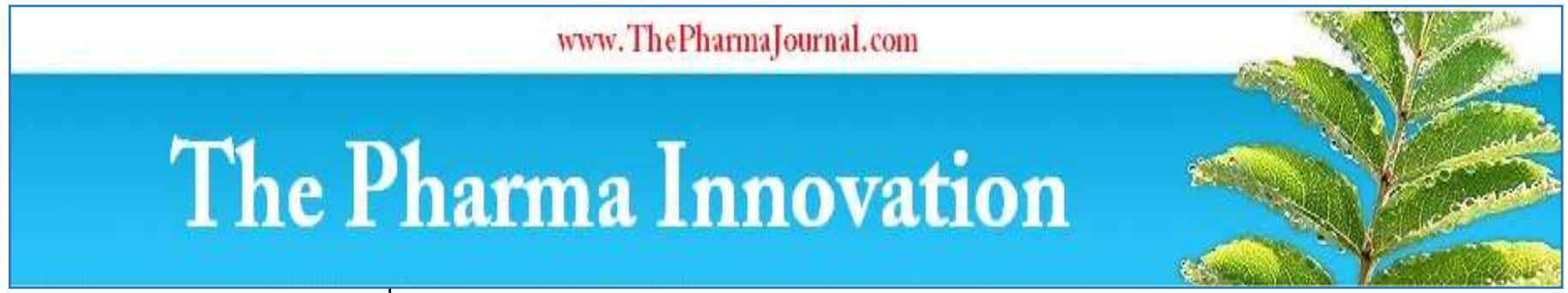

ISSN (E): 2277- 7695

ISSN (P): 2349-8242

NAAS Rating: 5.23

TPI 2021; SP-10(3): 103-106

(C) 2021 TPI

www.thepharmajournal.com

Received: 19-01-2021

Accepted: 24-02-2021

Yogesh Tiwari

PhD Scholar, Department of Agricultural Economics and

Farm Management, JNKVV, Jabalpur, Msdhya Pradesh,

India

\section{HO Sharma}

Professor, Department of Agricultural Economics and Farm Management, JNKVV, Jabalpur, Msdhya Pradesh, India

\section{PK Awasthi}

Professor, Department of Agricultural Economics and Farm Management, JNKVV, Jabalpur, Msdhya Pradesh, India
Corresponding Author:

\section{P Chitra}

Assistant Professor (V\&AS)

Department of Veterinary and

Animal Sciences Agricultural

College and Research Institute

Tamil Nadu Agricultural

University, Coimbatore

Tamil Nadu, India

\section{Constraints faced by the respondents in existing farming systems in Madhya Pradesh}

\author{
Yogesh Tiwari, HO Sharma and PK Awasthi
}

DOI: https://doi.org/10.22271/tpi.2021.v10.i3Sb.5850

\begin{abstract}
The present study was conducted in Umaria and Anuppur district of Madhya Pradesh with the specific objectives viz. to identify major constraints faced by the farmers in practicing different models of IFS. The study confined to two locations (Umaria and Anuppur) of AICRP on IFS, JNKVV, Jabalpur. All beneficiaries (120) under IFS have been selected for the study. An equal number of non-beneficiaries having similar socio-economic status also been selected for the study. Thus, total number of respondents $(120 \mathrm{X} 2)=240$. Four farming systems introduced in the study area, viz; FS-I: Crops + Dairy, FS-II: Crops + Dairy + Vegetable, FS-III: Crops + Dairy + Goatry, FS-IV: Crops + Dairy + Poultry. Major constraints faced by farmers in crop production in both the districts were, Low investment capacity, Lack of training facilities, Lack of credit facilities, High input cost. In livestock enterprises problems of unavailability of green fodder, unavailability of improved breeds, lack of scientific knowledge, and high cost of concentrate feed, low productivity, negative attitude towards innovative technologies. In vegetable production lack of training facilities, lack of technical knowhow, lack of knowledge about improved varieties, lack of transportation facilities. Major constraints for poultry farming were lack of knowledge, non-descript breed, non-availability of veterinary services and lack of transportation facilities.
\end{abstract}

Keywords: Existing farming systems, models of IFS, Madhya Pradesh

\section{Introduction}

Indian agriculture is characterized by decreasing holding size of farms, increasing population and labour charges, changing consumption behavior pattern and reduced availability of land and water resources besides which climate change and global warming are also the important challenges. With these issues, agriculture has responsibility of providing household food and nutritional security to billion plus population. The average operated size of holding which was 1.15 ha. In 2010-11 has declined to 1.08 ha. In 2015-16, at all India level. The small and marginal holdings taken together (0.00-2 ha.) constituted 86.08 per cent of the total holdings in 2015-16 against 85.01 per cent in 2010-11 while their share in the operated area stood at 46.94 per cent in the last census 2015 as against 44.58 per cent in 2010-11. (Agriculture Census, 2015-16) The decreasing trend of per capita land availability with shrinking operational farm holding size poses a serious challenge to the sustainability and profitability of existing farming systems especially in marginal and small households. Due to ever increasing population and decline in per capita availability of land in the country, practically there is no scope for horizontal expansion of land for agriculture. Indian agriculture currently faces a hast of diverse challenges due to the ever growing population increasing food and fodder needs, natural resource degradation, high cost of inputs and concerns of climate change phenomenal increase in food grain production upto 25.15 MT in the year 2015-16 could be achieved using improved technology including Integrated Farming System (IFS).

Integrated Farming Systems (IFS) are a whole farm management system which aims to deliver more sustainable agriculture. It is a dynamic approach which can be applied to any farming system around the world. Integrated Farming combines the best of modern tools and technologies with traditional practices according to a given site and situation. It is an interdependent, interrelated production systems based on few crops, animals and related subsidiary enterprises in such a way that maximize the utilization of nutrients of each system and minimize the negative effect of these enterprises on environment. The approach aims at increasing income and employment from small holding by integrating various farm enterprises and recycling crop residue and by product within the farm itself (Behera et al. 2004). 
A number of such illustrations can be given emphasizing the greater advantage of integrated farming system in generating technologies aimed at combating land degradation. It is the approach that can lead to a quantum jump in the productivity on a sustainable basis and ensure better livelihood securities to the people in fragile ecosystems. Farming system approach in analyzing the constraints of agriculture is gaining lot of importance in recent years. Keeping these aspects in view, the present study entitled "Constraints faced by the farmers in existing farming systems in Umaria and Anuppur district of Madhya Pradesh" has been undertaken.

\section{Methodology}

The study was conducted in Umaria and Anuppur district of Madhya Pradesh. Three villages selected from each block. IFS programme was undertaken in three villages in Karkeli block namely Ufri, Mahroi, Dadari and Manpur block in Saraswahi, Barbaspur and Maghgava villages of Umaria district. In Anuppur, undertaken in Damna, Parswar, Beribadh villages of Jatahari block and in Pushprajgarh block- Lalpur, Mototola, Kachrakola villages are selected. We select all 120 beneficiaries $(10 \times 6=120)$ and equal numbers of 120 nonbeneficiaries farmers were selected. Thus total number of respondents has been $120 \times 2=240.120$ farmers practicing crop alone, 72 farmers practicing Crop+ Dairy, 30 farmers practicing Crop+Dairy+Vegetable production, 14 farmers practicing Crop+Dairy+Goat farming and 4 farmers practicing Crop+Dairy+Poultry farming. Data were collected using structured pre-tested interview schedule through personal interview.

Garrett's ranking technique was used to analyze the constraints perceived by the respondents in integrated farming systems. The respondents were asked to rank the factors that limit in adoption of integrated farming systems. These orders of merit were transformed into units of scores by using the following formula.

Per cent position $=100 *\left(\mathrm{R}_{\mathrm{ij}}-0.5\right) / \mathrm{N}_{\mathrm{j}}$

Where,

$\mathrm{R}_{\mathrm{ij}}=$ Rank given for $\mathrm{i}^{\text {th }}$ factor (constraint) by $\mathrm{j}^{\text {th }}$ individual
$\mathrm{N}_{\mathrm{j}}=$ Number of factors (constraints) ranked by $\mathrm{j}^{\text {th }}$ individual The percent position was converted into scores by referring to the Table given by Garrett and Woodworth (1969) ${ }^{[1]}$. Then for each factor the scores of the individual respondents were added together and divided by the total number of respondents for whom scores were added. These mean scores for all the factors were arranged in descending order and the most influencing factors were identified through the ranks assigned.

\section{Result and discussion}

The constraints faced by the famers are discussed in five sub sections.

1. Constraints faced in Crop enterprises

2. Constraints faced in Dairy farming

3. Constraints faced in Vegetable production

4. Constraints faced in Goat farming

5. Constraints faced in Poultry farming

\subsection{Constraints faced in Crop enterprises}

Constraints faced by farmers in crop enterprises are presented in table 1. It is observed from the table that ten major of constraints were faced by farmers in crop production. Low investment capacity was the major constrains (Garrett score 63.35) faced by farmers. This is because most of the farmers considered for the study were of small and marginal. Lack of training facilities (Garrett score59.82) and Lack of credit facilities (Garrett score 54.36) were ranked at second and third position respectively. This was because most of the farmer were illiterate or had low schooling. Most of the training facilities were availed mostly by large farmers or progressive farmers. Small and marginal farmers were unable to get proper training due to the additional fact that they are reluctant to adopt and experience new techniques and methods in their farm. According to view point of farmers, High input cost was also an important constraint in practicing fourth with the score of 50.20. Among other constrains faced by the farmers were high market price fluctuations, lack of skill with family labour, lack of storage of facilities, nonavailability of improved varieties of seed, scarcity of labour and scattered land holdings.

Table 1: Constraints faced by beneficiaries under crop cultivation

\begin{tabular}{|c|c|c|c|c|}
\hline S. No. & Constrains & Total score & Garrett's score & Rank \\
\hline 1 & Low investment capacity & 7602 & 63.35 & I \\
\hline 2 & Lack of training facilities & 7178 & 59.82 & II \\
\hline 3 & Lack of credit facilities & 6523 & 54.36 & III \\
\hline 4 & High input cost & 6024 & 50.20 & IV \\
\hline 5 & High market price fluctuations & 5572 & 46.43 & V \\
\hline 6 & Lack of skill with family labour & 5128 & 42.73 & VI \\
\hline 7 & lack of storage of facilities & 5125 & 42.71 & VII \\
\hline 8 & Non-availability of improved varieties of seed & 4827 & 40.40 & VIII \\
\hline 9 & Scarcity of labour & 4752 & 40.23 & IX \\
\hline 10 & Scattered land holdings & 4526 & 38.42 & X \\
\hline
\end{tabular}

\subsection{Constraints faced in Dairy farming}

Constraints faced by farmers in livestock enterprises in both districts are presented in Table 2. Unavailability of green fodder was the major constrains (Garrett score 60.66) faced by farmers. This problem led to high input cost as the farmers have to purchase additional animal feed. Unavailability of improved breeds (Garrett score 58.66) and Lack of scientific knowledge (Garrett score 57.28) were ranked at second and third position respectively. This may be due to lack of knowledge and awareness about improving breeds or lack of credit to purchase these improves breeds. According to view point of farmers, High cost of concentrate feed was also an important constraint in practicing fourth with the score of 52.16. Among other constrains faced by the farmers were lack of information on govt schemes, lack of efficient transport and market facilities, lack of awareness, lack of financial support, high market price fluctuations and reduced grazing land for animals. 
Table 2: Constraints faced by beneficiaries under Dairy Enterprises

\begin{tabular}{|c|c|c|c|c|}
\hline S. No. & Constrains & Total score & Garrett's score & Rank \\
\hline 1 & Unavailability of green fodder & 7245 & 60.37 & I \\
\hline 2 & Unavailability of improved breeds & 7041 & 58.66 & II \\
\hline 3 & Lack of scientific knowledge & 6874 & 57.28 & III \\
\hline 4 & High cost of concentrate feed & 6314 & 52.16 & IV \\
\hline 5 & Lack of information on govt. schemes & 5867 & 48.88 & V \\
\hline 6 & Lack of efficient transport and market facilities & 5568 & 46.40 & VI \\
\hline 7 & Lack of awareness & 5142 & 42.85 & VII \\
\hline 8 & Lack of financial support & 4658 & 38.82 & VIII \\
\hline 9 & High market price fluctuations & 4265 & 35.54 & IX \\
\hline 10 & Reduced grazing land for animals & 4012 & 33.43 & X \\
\hline
\end{tabular}

Table 3: Constraints faced by beneficiaries for Vegetables Production

\begin{tabular}{|c|c|c|c|c|}
\hline S. No. & Constrains & Total score & Garrett's score & Rank \\
\hline 1 & Lack of training of scientific vegetable production technology & 1760 & 58.66 & I \\
\hline 2 & Lack of technical know how & 1642 & 54.73 & II \\
\hline 3 & Lack of knowledge about improved varieties & 1574 & 52.46 & III \\
\hline 4 & Price fluctuations & 1556 & 51.86 & IV \\
\hline 5 & Lack of transportation facilities & 1321 & 44.03 & V \\
\hline 6 & Difficulty in diagnosis of disease and pest & 1318 & 43.93 & VI \\
\hline 7 & Non-availability of facilities of soil testing & 1284 & 42.80 & VII \\
\hline 8 & Poor market facilities & 1242 & 41.41 & VIII \\
\hline 9 & Market are distantly located & 1237 & 41.23 & IX \\
\hline 10 & Lack of irrigation facilities & 1173 & 39.12 & X \\
\hline
\end{tabular}

\subsection{Constraints faced in vegetable production}

Lack of training of scientific vegetable production technology was the major constrains (Garrett score 58.66) faced by farmers. Lack of technical knowhow (Garrett score 54.46) and Lack of knowledge about improved varieties (Garrett score 51.86) were ranked at second and third position respectively. Since vegetable crops needs proper management practices, which are ignored by most of the farmers. It is necessary for the vegetable groves that, they should follow training programme related to scientific vegetable production which boost higher productivity of vegetables. According to view point of farmers, price fluctuations were also an important constraint in practicing fourth with the score of 44.03. Among other constrains faced by the farmers were difficulty in diagnosis of disease and pest, non-availability of facilities of soil testing, poor market facilities, market are distantly located and lack of irrigation facilities.

Table 4: Constraints faced by beneficiaries for Goat faming

\begin{tabular}{|c|c|c|c|c|}
\hline S. No. & Constrains & Total score & Garrett's score & Rank \\
\hline 1 & Lack of grazing area & 821 & 58.64 & I \\
\hline 2 & Negative attitude towards innovative technologies & 816 & 58.25 & II \\
\hline 3 & Low productivity & 765 & 54.64 & III \\
\hline 4 & Lack of knowledge on disease & 724 & 51.71 & IV \\
\hline 5 & Low prestige with goat rearing & 683 & 48.76 & V \\
\hline 6 & Rearing of non-descript breed & 641 & 45.75 & VI \\
\hline 7 & Lack of preventive health management & 611 & 43.64 & VII \\
\hline 8 & Unavailability of vaccines & 578 & 41.27 & VIII \\
\hline 9 & Unavailability of specific market & 543 & 38.78 & IX \\
\hline 10 & Lack of credit facilities & 36.42 & X \\
\hline
\end{tabular}

\subsection{Constraints faced in Goat rearing}

Lack of grazing area was the major constrains (Garrett score 58.64) faced by farmers. Because of which the grazing land is getting scarce and goat rearing farmers are unable to feed their goats. Because of which the grazing land is getting scarce and goat rearing farmers are unable to feed their goats. Negative attitude towards innovative technologies (Garrett score 58.25) and low productivity (Garrett score 54.64) were ranked at second and third position respectively. This may be due to lack of interference of government policies into goat farming along with their interest into this particular sector. According to view point of farmers, low prestige with goat rearing was also an important constraint in practicing fourth with the score of 51.71. Among other constrains faced by the farmers were rearing of non-descript breed, lack of preventive health management, unavailability of vaccines, unavailability of specific market and lack of credit facilities. 
Table 5: Constraints faced by beneficiaries for poultry farming

\begin{tabular}{|c|c|c|c|c|}
\hline S. No. & Constrains & Total score & Garrett's score & Rank \\
\hline 1 & Lack of knowledge & 234 & 58.50 & I \\
\hline 2 & Non descript breed & 203 & 50.75 & II \\
\hline 3 & Non-availability of veterinary services & 185 & 46.25 & III \\
\hline 4 & Lack of transportation facilities & 143 & 35.75 & IV \\
\hline 5 & Seasonal demand & 114 & 28.50 & V \\
\hline 6 & Lack of proper housing & 102 & 25.50 & VI \\
\hline
\end{tabular}

\subsection{Constraints faced in Poultry farming}

Lack of knowledge was the major constrains (Garrett score 58.50) faced by farmers. The lack of knowledge may be due to the fact that most of the farmers were illiterate or had low education. The poultry production also needs knowledge regarding various methods and lack of these will lead to poor productivity. Non-descript breed (Garrett score 50.75) and non-availability of veterinary services (Garrett score 46.25) were ranked at second and third position respectively. This shows lack of knowledge among farmers regarding indigenous breeds which will yield good returns. According to view point of farmers, lack of transportation facilities was also an important constraint in practicing fourth with the score of 35.75. Among other constrains faced by the farmers were seasonal demand and lack of proper housing.

\section{Conclusion}

The study revealed that, in terms of crop enterprise low investment capacity was the major constraint in the study area. This is because most of the farmers considered for the study were of small and marginal. Lack of training facilities were other important constraints faced by the farmers. Regarding Dairy enterprise unavailability of green fodder in village was major constraint, unavailability of improved breeds, lack of scientific knowledge were major problems faced by the farmers. In terms of horticulture enterprise, lack of training of scientific vegetable production technology, lack of technical knowhow, lack of knowledge about improved varieties. In goat farming lack of grazing area, negative attitude towards innovative technologies, low productivity were the major constraints and in poultry farming, lack of knowledge, non-descript breed, non-availability of veterinary services were the main major constraints faced by the farmers in study area.

\section{References}

1. Garrett HE, Woodworth RS. Statistics in Psychology and Education. Vakils, Feffer and Simons Pvt. Ltd. Bombay 1969, 329.

2. Helen S, Rejina Vasudevan T, Vinod T. Constraints in Coconut-based Homestead farming in the high rainfall coastal agro-ecosystem of central Kerala. Indian Farm 2007;58(12):3-4.

3. Jana H, Verma HK. Constraints faced by the paddy growers in adoption of recommended plant protection practices. Rural India 2004;67(6-7):122.

4. Nagaraju D, Gopal Sankhala. Constraints among Koya in production of improved dairy practices. The Andhra Pradesh Journal 2003;50(3\&4):337-341.

5. Patil VG. The Constraints faced by the dairy farmers. Financing Agriculture 2009;41(5):24-27.

6. Pushpa J. Constraints in various integrated farming systems. Agriculture Update 2011;5(4):370-374.

7. Sharma KC, Panwar P, Singh P, Nitharwal BS. Major constraints in adoption of maize production technology in
Bhilwara district of Rajasthan. Green Farming 2012;3(5):547-550.

8. Singh H, Burark SS, Meena GL, Bhushan Bharat, Meena Kamalesh. Constraints faced by the households in existing farming systems in Chittorgarh and Banaswara districts of Southern Rajasthan. Journal of Animal Research 2016;6(6):1031-1035. 